\title{
Estimated Mean Blood Pressure
}

National Cancer Institute

\section{Source}

National Cancer Institute. Estimated Mean Blood Pressure. NCI Thesaurus. Code C135376.

The estimated average blood pressure. 